\title{
Effects of acute recombinant humanTSH on serum ghrelin levels
}

\author{
Cristina Ciuoli, Lucia Brusco, Alexandra Theodoropoulou, Maria Grazia Castagna, Ornella Neri, \\ Letizia Pasqui and Furio Pacini*
}

Section of Endocrinology, Department of Internal Medicine, Endocrinology and Metabolism and Biochemistry, University of Siena, Siena, Italy

Edited by:

Bernadette Biondi, Federico II

University of Naples, Italy

Reviewed by:

Bernadette Biondi, Federico II

University of Naples, Italy

Rosa Marina Melillo, University of

Naples Federico II, Italy

${ }^{*}$ Correspondence:

Furio Pacini, Section of

Endocrinology, University of Siena,

Via Bracci, 53100 Siena, Italy.

e-mail: pacini8@unisi.it
Recent findings showed the presence of a reciprocal relationship between thyroid hormones and ghrelin, although the exact mechanism is not known. Design: Our study is addressed to evaluate the effect of acute exogenous rhTSH administration on serum ghrelin levels in athyreotic patients on replacement I-thyroxine therapy. The study group included 50 patients (16 males and 34 females) submitted to total thyroidectomy and 131-iodine remnant ablation for differentiated thyroid cancer on l-thyroxine therapy. Mean age was $47.5 \pm 16.5$ years and mean BMI was $25.6 \pm 5.01 \mathrm{~kg} / \mathrm{m}^{2}$. rhTSH was administrated the dosage of $0.9 \mathrm{mg}$ i.m. once daily for two consecutive days. Blood samples were taken between 08.00 and 09.00 after a overnight fasting for measurement of TSH, FT3, FT4, and ghrelin before the first administration of rhTSH and for measurement of TSH and ghrelin $24,48,72$, and $96 \mathrm{~h}$ after the first administration of rhTSH. Results: Mean \pm SD values of basal TSH were $0.54 \pm 0.77 \mu \mathrm{U} / \mathrm{ml}$ without significant difference between females and males. As expected, after rhTSH administration TSH concentrations increased at 24 and $48 \mathrm{~h}$ with peakTSH values ranging from 20.20 to $313 \mu \mathrm{U} / \mathrm{ml}$ (mean \pm SD $98.4 \pm 66.7 \mu \mathrm{U} / \mathrm{ml}$ ). Mean \pm SD values of basal ghrelin were $1085 \pm 373 \mathrm{pg} / \mathrm{ml}$ without significant difference between males and females. After rhTSH administration ghrelin concentrations decreased significantly $(p<0.01)$ at $24 \mathrm{~h}($ mean \pm SD $934 \pm 314 \mathrm{pg} / \mathrm{ml} p<0.01)$ and returned to pretreatment levels at $96 \mathrm{~h}$. Conclusion: Our study demonstrates that acute exogenous TSH administration has a suppressive effect on ghrelin secretion independent from changes in thyroid status.

Keywords: TSH, ghrelin

\section{INTRODUCTION}

Ghrelin, an acylated 28-amino acid ligand for the growth hormone secretagogue receptor (GHS-R), is produced principally by the neuroendocrine X/A cells of the gastric mucosa (Kojima and Kangawa, 2005). It was also identified in the pituitary gland, hypothalamus, pancreas, and others tissues (Date and Kojima, 2000). At the hypothalamic level, ghrelin stimulates GH release and regulates appetite and energy balance (Waren and Small, 2000; Ghigo and Arvat, 2001). Increased levels are seen in catabolic conditions (Misra and Miller, 2005), and decreased levels are found in obese patients (Marchesini and Bianchi, 2004). Moreover, an inverse correlation between serum ghrelin levels and resting energy expenditure (REE) has been recorded in healthy women (Kamiji and Troncon, 2010). Thyroid disease is associated with changes in appetite, food intake, and REE. Previous studies have reported decreased levels of ghrelin in hyperthyroidism (Altinova and Toruner, 2006a) and increased levels in hypothyroid patients (Gjedde and Vestergaard, 2008; Kosowicz and Baumann-Antczak, 2011). On the other hand it has been recently demonstrated the presence of mRNA of GHS-R in thyroid tissues (Ueberberg and

Abbreviations: BMI, body mass index; GHS-R, growth hormone secretagogue receptor; TSH, thyroid stimulating hormone.
Unger, 2009) and a stimulating effect of ghrelin on FT4 secretion in vivo (Kluge and Riedl, 2010), suggesting a reciprocal effect between ghrelin and thyroid hormones. Since previous studies were conducted in patients with abnormal thyroid hormone levels (hyperthyroidism and hypothyroidism) they could not assess the direct role of TSH on ghrelin secretion. The present study was designed in athyreotic patients in stable replacement l-thyroxine therapy and normal TSH to study the effect of exogenous TSH administration independent of thyroid status.

\section{PATIENTS AND METHODS}

The study group included 50 patients (16 males and 34 females) submitted to total thyroidectomy and 131-iodine remnant ablation for differentiated thyroid cancer. Mean age was $47.5 \pm 16.5$ years and mean BMI was $25.6 \pm 5.01 \mathrm{~kg} / \mathrm{m}^{2}$. Twentyeight patients with persistent disease or at high risk, received 1-thyroxine in suppressive or semisuppressive doses (target TSH $<0.5 \mu \mathrm{IU} / \mathrm{mL}$ ), 22 patients, who had previous evidence of complete remission, were treated with replacement doses of l-thyroxine aimed to maintain normal TSH concentration.

Patients were scheduled to receive rhTSH (Thyrogen; Genzyme Therapeutics, Cambridge, MA, USA) for periodic staging of their disease. rhTSH was administrated at the dosage of $0.9 \mathrm{mg}$ i.m. once daily for two consecutive days according to conventional protocol 
(Pacini and Ladenson, 2006). Blood samples were taken between 08.00 and 09.00 after a overnight fasting for measurement of TSH, FT3, FT4, and ghrelin before the first administration of rhTSH and for measurement of only TSH and ghrelin 24, 48, 72, and $96 \mathrm{~h}$ after the first administration of rhTSH.

Serum total ghrelin was determined by a validated radioimmunoassay (RIA; Mediagnost, Reutlingen, Germany) with a functional sensitivity described by the manufacturer of $0.04 \mathrm{ng} / \mathrm{ml}$; the normal range is $600-1400 \mathrm{pg} / \mathrm{ml}$. Serum TSH was determined by a commercially chemiluminescent assay (Immulite 2000, third generation TSH, Los Angeles, CA, USA; EURO/DPC limited Lamberies, Gwynedd, UK).

\section{STATISTICAL ANALYSIS}

Data are presented as mean \pm SD. Statistical analysis was performed using the Mann-Whitney test when comparing nonparametric data. Areas under the serum concentration curves (AUC) of ghrelin and TSH were calculated for the intervals 0$96 \mathrm{~h}$ by applying the trapezoid rule. One-way ANOVA was conducted to compare serum ghrelin concentration at various time points. Post hoc comparisons were conducted using Bonferroni's correction. Correlations between the variables were analyzed by Pearson analysis using the Graph Pad Prism version 3.0. Statistical significance was defined as $p$ value $<0.05$.

\section{RESULTS}

Mean \pm SD values of basal TSH were $0.54 \pm 0.77 \mu \mathrm{U} / \mathrm{ml}$ without significant difference between females and males. As expected, after rhTSH administration TSH concentrations increased at 24 and $48 \mathrm{~h}$ with peak TSH values ranging $20.2-313 \mu \mathrm{U} / \mathrm{ml}$ (mean \pm SD $98.4 \pm 66.7 \mu \mathrm{U} / \mathrm{ml}$ ). In most patients (42 patients) the peak serum TSH was observed $48 \mathrm{~h}$ after the second rhTSH injection. The TSH-AUC was positively associated with age $(r=0.55, p<0.0001)$, but not with BMI. Mean $\pm \mathrm{SD}$ values of basal ghrelin were $1085 \pm 373 \mathrm{pg} / \mathrm{ml}$ without significant difference between males and females. After rhTSH administration ghrelin concentrations decreased significantly $(p<0.01)$ at $24 \mathrm{~h}$ (mean \pm SD $934 \pm 314 \mathrm{pg} / \mathrm{ml} p<0.01)$ and returned to pretreatment levels at $96 \mathrm{~h}$ (Figure 1). As shown in Figure 2 a negative correlation between ghrelin AUC and BMI was observed $(r=-0.37, p=0.008)$.

\section{DISCUSSION}

In vitro studies demonstrated that both ghrelin and GHR-S are expressed in normal and neoplastic thyroid glands (Gnanapavan and Kola, 2002; Zhang and Wang, 2006; Karaoglu and Aydin, 2009; Ueberberg and Unger, 2009) and a reciprocal relationship between thyroid hormones and ghrelin levels has been demonstrated (Chrysanthia and Franchi, 2007). In vivo some studies have shown that ghrelin levels are reduced in overt hyperthyroidism, but not in subclinical hyperthyroidism (Tanda and Lombardi, 2009), and are normalized after correction of hyperthyroidism (Riis and Hansen, 2003). However it is not clear whether ghrelin reduction is a consequence of excess thyroid hormones or secondary to the hyperinsulinemic status associated with hyperthyroidism (Gimenez-Palop and Gimenez-Perez,


2005). More conflicting data are reported in hypothyroid patients with studies showing higher, normal, and even lower serum ghrelin levels (Gimenez-Palop and Gimenez-Perez, 2005; Altinova and Toruner, 2006b; Gjedde and Vestergaard, 2008; Tanda and Lombardi, 2009).

Our model of athyreotic patients replaced with 1-thyroxine consented to study the effect of TSH on ghrelin concentrations independently of thyroid status. We observed a decrease of ghrelin levels in the first $24 \mathrm{~h}$ from rhTSH administration returning to baseline thereafter. We did not observe gender difference in TSH-stimulated ghrelin concentrations, but, as expected, we found a negative correlation between basal and TSH-stimulated ghrelin levels and BMI. The observation that the correlation persists also after TSH stimulation is an indication that the effect of TSH is a true biological phenomenon rather than a fortuitous finding. Although we injected pharmacological doses of rhTSH, we want to notice that the TSH levels achieved in the blood are similar to those obtained after thyroid hormone withdrawal in thyroid cancer patients undergoing routine follow-up examination.

In conclusion, our study shows that a modulator action of TSH is operating at gastric mucosa on ghrelin secretion, at least at acute pharmacological doses. 


\section{REFERENCES}

Altinova, A. E., and Toruner, F. B. (2006a). Reduced serum acylated ghrelin levels in patients with hyperthyroidism. Horm. Res. 65, 295-299.

Altinova, A. E., and Toruner, F. (2006b). Serum ghrelin levels in patients with Hashimoto's thyroiditis. Thyroid 16, 1259-1264.

Chrysanthia, A. L., and Franchi, G. (2007). Ghrelin in neuroendocrine organs and tumors. Pituitary 10, 213-225.

Date, Y., and Kojima, M. (2000). Ghrelin, a novel growth hormonerealising acylated peptide, is synthesized in a distinct endocrine cell type in the gastrointestinal tracts of rats and humans. Endocrinology 141, 4255-4261.

Ghigo, E., and Arvat, E. (2001). Biologic activities of growth hormone secretagogues in humans. Endocrine 14, 87-93.

Gimenez-Palop, O., and GimenezPerez, G. (2005). Circulating ghrelin in thyroid dysfunction is related to insulin-resistance and hunger, food-intake or anthropometric changes. Eur. J. Endocrinol. 153, 73-79.

Gjedde, S., and Vestergaard, E. T. (2008). Serum ghrelin levels are increased in hypothyroid patients and become normalized by L-thyroxine treatment. J. Clin. Endocrinol. Metab. 93, 2277-2280.

Gnanapavan, S., and Kola, B. (2002). The tissue distribution of the mRNA of ghrelin and subtypes of its receptor, GHS-R, in humans. J. Clin. Endocrinol. Metab. 87, 2988-2991.

Kamiji, M. M., and Troncon, L. E. (2010). Ghrelin and PYY (3-36) in gastrectomized and vagotomized patients: relations with appetite, energy intake, and resting energy expenditure. Eur. J. Clin. Nutr. 64, 845-852.

Karaoglu, A., and Aydin, S. (2009). Expression of obestatin and ghrelin in papillary thyroid carcinoma. Mol. Cell. Biochem. 323, 113-118.

Kluge, M., and Riedl, S. (2010). Ghrelin affects the hypothalamus-pituitarythyroid axis in humans by increasing free thyroxine and decreasing TSH in plasma. Eur. J. Endocrinol. 162, 1059-1065.

Kojima, M., and Kangawa, K. (2005). Ghrelin: structure and function. Physiol. Rev. 85, 495-522.

Kosowicz, J., and Baumann-Antczak, A. (2011). Thyroid hormones affect plasma ghrelin and obestatin levels. Horm. Metab. Res. 43, 121-125.

Marchesini, G., and Bianchi, G. (2004). Plasma ghrelin concentrations, food intake, and anorexia in liver failure.
J. Clin. Endocrinol. Metab. 89 2136-2141.

Misra, M., and Miller, K. K. (2005). Secretory dynamics of ghrelin in adolescent girls with anorexia nervosa and healthy adolescents. Am. J. Physiol. Endocrinol. Metab. 289, 347-356.

Pacini, F., and Ladenson, P. W. (2006). Radioiodine ablation of thyroid remnants after preparation with recombinant human thyrotropin in differentiated thyroid carcinoma: results of an international, randomized, controlled study. J. Clin. Endocrinol. Metab. 91, 926-932.

Riis, A. L., and Hansen, T. K. (2003). Hyperthyroidism is associated with suppressed circulating ghrelin levels. J. Clin. Endocrinol. Metab. 88, 853-857.

Tanda, M. L., and Lombardi, V. (2009). Plasma total and acylated ghrelin concentrations in patients with clinical and subclinical thryoid dysfunction. J. Endocrinol. Invest. 32, 74-78.

Ueberberg, B., and Unger, N. (2009). Expression of ghrelin and its receptor in human tissues. Horm. Metab. Res. 41, 814-821.

Waren, A. M., and Small, C. J. (2000). The novel hypothalamic peptide ghrelin stimulates food intake and growth hormone secretion. Endocrinology 141, 4325-4328.
Zhang, Y. F., and Wang, H. N. (2006). Ghrelin expression in the tissues of different thyroid diseases. Beijing Da Xue Xue Bao 38, 193-196.

Conflict of Interest Statement: The authors declare that the research was conducted in the absence of any commercial or financial relationships that could be construed as a potential conflict of interest.

Received: 28 September 2011; accepted: 21 November 2011; published online: 16 December 2011.

Citation: Ciuoli C, Brusco L, Theodoropoulou A, Castagna MG, Neri O, Pasqui $L$ and Pacini F (2011) Effects of acute recombinant human TSH on serum ghrelin levels. Front. Endocrin. 2:94. doi 10.3389/fendo.2011.00094

This article was submitted to Frontiers in Thyroid Endocrinology, a specialty of Frontiers in Endocrinology.

Copyright (C) 2011 Ciuoli, Brusco, Theodoropoulou, Castagna, Neri, Pasqui and Pacini. This is an open-access article distributed under the terms of the Creative Commons Attribution Non Commercial License, which permits noncommercial use, distribution, and reproduction in other forums, provided the original authors and source are credited. 